\title{
ACCENTS OF THE HUMAN BODY ELECTROMAGNETIC BALANCE REGULATION SYSTEM
}

\author{
S.A. Gulyar \\ Dr. Sci. (Med.), Prof., Leading Researcher \\ A.A. Bogomolets Institute of Physiology of NASU \\ 4 Bogomoletz St., Kyiv, 01024, Ukraine \\ International Medical Innovation Center, Kiev, Ukraine \\ tel.: +38 (050) 411-16-32 \\ e-mail:gulyar@zepter.ua \\ ORCID 0000-0003-2128-7656
}

The presented analytical review includes data about the current state of knowledge on the electromagnetic ecological background influencing all living organisms. It is demonstrated that a non-specific morbidity can result from an electromagnetic imbalance and free-radical overloading resulting from disturbed ecology. We postulate the existence of a separate functional system of the electromag-netic regulation in the organism, and a working concept of phototherapy application is formulated. It is based on the possibility of using acupuncture points for energy compensation from electromagnetic waves of a biologically necessary range in the system of their conductors in the organism. This system can be considered as a tool for transmitting polarized electromagnetic waves in a visible light range.

Organs subjected to an electromagnetic imbalance because of an excess of the biologically inadequate irradiations and serving as targets for peroxidation-induced influences, i.e., neurohormonal and immune regulatory systems of the organism, are qualified as recipient zones. Subsequent electromagnetic stimulation or modification of the functions of the recipient zones result in positive curative effects; combination of the latter with local reparative processes allows one to provide positive clinical shifts in persons subjected to the respective treatment.

Natural possibilities allowing one to compensate deficiency in electromagnetic waves of the "solar" range are limited. Applications of PILER-light generated by BIOPTRON-type devices can be considered an adequate alternative. Combined application of local and systemic electromagnetic influences of the waves of a biologically necessary (visible light) range with the use of the principles of light therapy concepts constitutes a crucial feature of the modern approach.

At present, problems of judicial and medical legalization of light- and color therapy, questions of the main mechanisms of the effects of PILER-light, a field of the medical reasons for its application, first generations of the curative modes, and color therapy curative programs can be considered settled.

Among outstanding questions, in general directed toward the expansion of application of the PILER-light therapy technologies, the first place is occupied by a necessity for the development of new experimentally grounded curative programs and antipain techniques provided by color therapy.

Key words: BIOPTRON, PILER-light, electromagnetic waves, electromagnetic technology, electromagnetic imbalance, phototherapy, color therapy, polarized light, acupuncture points, energetical meridians, pain, immunity, visceral systems

\section{АКЦЕНТИ СИСТЕМИ РЕГУЛЮВАННЯ ЕЛЕКТРОМАГНІТНОГО БАЛАНСУ ОРГАНІЗМУ ЛЮДИНИ}

\section{С.О. Гуляр}

Інститут фізіологій ім. О.О.Богомольця НАН Украӥни, м. Київ, Украӥна

Інтернаціональний медичний інноваційний центр, м. Київ, Україна

Наведено аналітичний огляд, що містить сучасний стан знань про вплив електромагнітного екологічного тла на живі організми. Встановлено, що неспецифічна захворюваність є результуючим наслідком електромагнітного дисбалансу і вільнорадикальних перевантажень (інтоксикацій) - двох основних комплексів екологічних факторів.

Сформульована робоча концепція світлотерапії, згідно з якою точки акупунктури можуть бути використані для поповнення енергії від біологічно необхідних електромагнітних хвиль. Подальший їх транспорт здійснюється через спеціальні провідні шляхи (електромагнітний каркас). До органіводержувачів віднесені органи, які відчувають електромагнітний дисбаланс в зв'язку з надлишком негативних випромінювань, інтоксикаційним перевантаженням вільними радикалами - нейрогормональна і імунна 
системи організму. Відновлення їх стану забезпечує лікувальний ефект, а з урахуванням місцевих регенеративних процесів в зоні освітлення, він стає найбільшим. Можливості поповнення дефіциту сонячної енергії обмежені, повноцінним иї замінником є ПАЙЛЕР-світло, створенеапаратом БІОПТРОН.

Особливості сучасного підходу до світлотерапії полягають в комбінованому застосуванні місцевого і системного (через точки акупунктури) електромагнітного впливу ПАЙЛЕР-світлом. На теперішній час світло- і колортерапія отрималио фіційне визнання, визначені основні механізми дії ПАЙЛЕР-світла, покази та лікувальні режими його застосування. Подальший пошук спрямований на розширення застосування ПАЙЛЕР-світлотерапевтичних технологій, зокрема, зі створення нових лікувальних програм і розробці протибольових методик колортерапіі.

Ключові слова: БІОПТРОН, ПАЙЛЕР-світло, електромагнітні хвилі, електромагнітнітехнології, електромагнітний дисбаланс, світлотерапія, колортерапія, поляризованесвітло, точки акупунктури, енергетичні меридіани, біль, імунітет, вісцеральні системи

\section{АКЦЕНТЫ СИСТЕМЫ РЕГУЛЯЦИИ ЭЛЕКТРОМАГНИТНОГО БАЛАНСА ОРГАНИЗМА ЧЕЛОВЕКА}

\section{С.А. Гуляр}

Институт физиологии им. А.А.Богомольца НАН Украины, г. Киев, Украина

Интернациональный медицинский инновационный центр, г. Киев, Украина

Представлен аналитический обзор, включающий современное состояние знаний о влиянии электромагнитного экологического фона на живые организмы. Установлено, что неспецифическая заболеваемость является результирующим следствием электромагнитного дисбаланса и свободно радикальных перегрузок (интоксикаций) - двух основных комплексов экологических факторов.

Сформулирована рабочая концепция светотерапии, согласно которой точки акупунктуры могут быть использованы для восполнения энергии от биологически необходимых электромагнитных волн. Дальнейший их транспорт осуществляется через специальные проводящие пути (электромагнитный каркас). К органам-получателям отнесены органы, испытывающие электромагнитный дисбаланс в связи с избытком негативных излучений, интоксикационную перегрузку свободными радикалами - нейрогормональная и иммунная системы организма. Восстановление их состояния обеспечивает лечебный эффект, а с учетом местных регенеративных процессов в зоне освещения, он становится наибольшим. Возможности восполнения дефицита солнечной энергии ограничены, полноценным ее заменителем является ПАЙЛЕР-свет, создаваемый аппаратом БИОПТРОН.

Особенности современного подхода при светотерапии заключаются в комбинированном применении местного и системного (через точки акупунктуры) электро-магнитного воздействия ПАЙЛЕР-светом. К настоящему времени свето- и колортерапия получили официальное признание определены основные механизмы действия ПАЙЛЕР-света, показания и лечебные режимы его применения. Дальнейший поиск направлен на расширение применения ПАЙЛЕР-светотерапевтических технологий, в частности, по созданию новых лечебных программ и разработке противоболевых методик колортерапии.

Ключевые слова: БИОПТРОН, ПАЙЛЕР-свет, электромагнитные волны, электромагнитные технологии, электромагнитный дисбаланс, светотерапия, колортерапия, поляризованныйсвет, точки акупунктуры, энергетические меридианы, боль, иммунитет, висцеральные системы.

\section{Introduction to electromagnetic ecology}

Millions of years of life on Earth, the subsequent development of mammals and humans occurred in conditions of relatively constant exposure to electromagnetic fields (electromagnetic waves) that had natural fluctuations depending on the space and solar activity, the Earth and the Moon rotation. Accordingly, for such an important environmental factor there could not be developed physiological mechanisms of adaptation. It is also physiologically reasonable, the existence of mechanisms that utilize electromagnetic energy to ensure the needs of the current metabolic processes. In other words, electromagnetic background has some influence on the organism functional systems, and its fluctuations in the range greater than natural fluctuations (magnetic storms), cannot help but reflect on their state. It follows that in the pathogenesis of many states of the organism, pre diseases, immunodeficiency and diseases, a significant role may play electromagnetic destabilization [35].

As an electric potential difference occurs in general on the Earth (the stratosphere - the surface) the same for the human body (head - feet), static electricity which is accumulated mainly on the skin determines the effect of electrical charges on the skin structure, and internal organs $[2,7,71]$. His fluctuation, for example, at changing weather conditions distort nerve impulses from the skin receptor areas, causing various deviations of autonomic functions. These phenomena are evident in individuals with hypersensitivity to electromagnetic differences (meteopaths). I should add that there are electromagnetic fields of the brain, heart and other organs, that interact with the magnetic fields of the Earth and artificial (man-made) 
electromagnetic fields (table 2). There are described many evolutionarily developed adaptive mechanisms of of body regulation functions, that depend on the electromagnetic environment: electromagnetic field orientation, presence of "biological watch" (coordinated with diurnal variation of the geomagnetic field, or time-shifted depending from latitude to latitude), "group navigation system of birds" and et al. [69]. One consider that the biorhythms of functional systems determine the quality of the reproductive function, rate of aging, and development of life-threatening disease (malignant tumors, diabetes) [11].

Empirically, perhaps, without fully realizing, the electromagnetic nature of disease, the ancient Chinese, Tibetan and Indian healers have developed technology options of acupuncture based on mechanical stimulation of structures related to the regulation of the body functions [42, 50, 57, 59, 60, 66, 68, 74, 79]. If you do not take into account the religious and mystical layers, this technology has a quite slender structure from the position of electromagnetic supply of the fundamental biophysical processes proper functioning. This process has a history of evolution lasting millions of years, as identical acupuncture points are revealed in humans and different mammals.

An important proof of the existence of the reaction zone, referred to as acupuncture points, were the results of experimental studies of analgesia. During formalin model on animalswe obtained confirmation of the role of poly- and monochromatic polarized light application at E-36 acupuncture point [55]. We also revealed participation of opioidergich analgesic system, indicating on association of acupuncture points and structures located in the central nervous system [53] (Fig. 1).

So far, the hypothesis is formulated [50] that the acupuncture points can be considered as electromagnetic waves receptors, perceiving them for further transport to various organs and tissues through the meridians that are the best conductors of electromagnetic waves in comparison with the surrounding tissues. Subsequent studies confirmed the possibility of non-contact conduct of the electromagnetic waves of microwave and visible ranges of the acupuncture points to the different levels of the central nervous system $[13,24,48,53,65,67,74]$ and it is found that at pain syndrome effect reaches the level of endogenous opioid systems in the brain [48]. This, parallel to anatomical structures, electromagnetic or meridian "Skeleton" is probably a quite workable form, because in the effectiveness of acupuncture no one is in doubt now. There only remains the ancient prejudice of the doctors standing on the positions of the European classical medicine, about the absence of a material substrate for the eastern technologies.

Electromagnetically sensitive acupuncture points have a number of distinguishing features, in comparison with the surrounding tissues, and can perceive electromagnetic waves of different frequencies (light from different sources, microwave, that of very high frequency, man-made radiation, although a natural stimulant is a natural solar spectrum), causing subsequent resonant responses from atomic and molecular structures, which have functional connection with these points [50, 73]. Moreover, depending on the natural variability of the Sun and probably lunar phases affecting terrestrial magnetism, the acupuncture points may change their sensitivity, becoming "open" and "closed".

Recently, there are obtained data on the collagen semiconducting properties, which in combination with water molecules joint into cluster structures defines liquid crystalline properties of the connective tissue. This approach, based on the above concept, explains the discrepancy between anatomical and functional efficiency, uncertainty of the concept "meridians" or "channels" in terms of oriental medicine [36]. The main grounds of the authors of this approach can be formulated as follows:

- The system of acupuncture points, meridians and constant electromagnetic field of the body belong to a holistic system of liquid-crystal fibers of collagen, which is the basis for connective tissue.

- Meridians - are oriented collagen fibers, surrounded by layers of bound water, provide permanent proton conductive pathways for rapid interconnection of all structures of the body, providing its functioning as an integrated system.

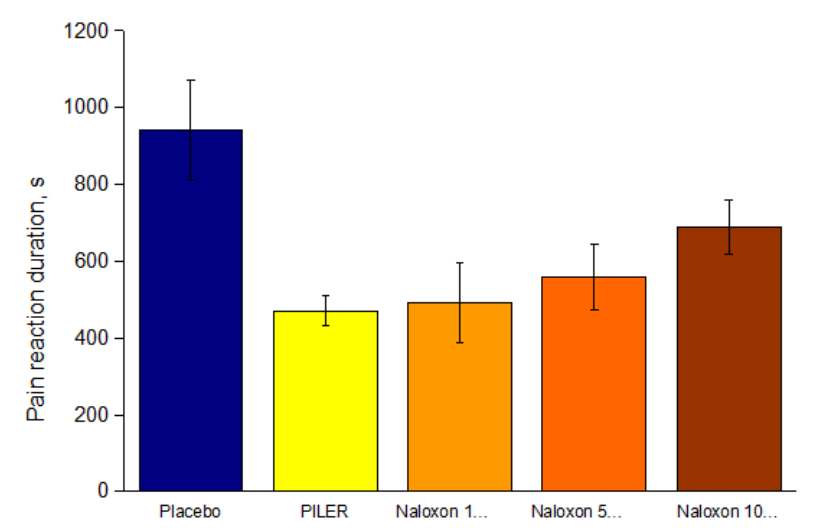

Fig. 1. The effect of naloxone blockade of opiate receptors on tonic pain:

Duration of the pain response (pain focus licking) observed for 60 min after influenceon E-36 acupuncture point inthe animals of the control group (placebo) and the four experimental groups receiving only Pilar-light and in combination with doses of naloxone 1,5 and $10 \mathrm{mg} / \mathrm{kg}$. The figure illustrates the existence of the objective biological reaction in response to the contactless light application on acupuncture point, the existence of the connection between a remote area (point E-36 is located on the upper third of the leg) and subcortical analgesic centers, as well as the opportunity to receive clinical outcome (analgesia). Blockade of the receptors of the brain opioidergic system is illustrated by analgesia reduction at increased dose of naloxone. 
-The liquid crystal "network" is involved

- in quick response to electromagnetic waves;

- the ability to respond to the trace substances (homeopathy);

- the formation of hyper-reactivity to allergens;

- emergency responses to damage.

- The liquid crystal "network" provides a link between somatic and neural structures.

To provide the mentioned processes, peculiarities of collagen structure are important, which consists of chains of molecules of tropocollagen, length $280 \mathrm{~nm}$, which are oriented longitudinally parallel. These molecules do not mutually adjoin, there is a gap between them and the adjacent molecules overlap slightly. The length of the molecules is 4.4 times larger than its diameter. Tropocollagen triple helix is stabilized by hydrogen bonds between individual chains [63].

It is exactly this structure, which is the most convenient for uneven transmission of electromagnetic signals, i.e., for facilitated in the longitudinal direction. The network of collagen and elastin fibers, available in the connective tissue can probably carry both longitudinal transport of signals, for example, along the limbs and body, and irradiation of their part into the tissue depth. Location of the connective tissue around the nerve structures improves the signals broadcast into nerve fibers, which may facilitate the involvement of the nervous system in the generalized network reactions.

On the other hand, it is assumed that on the ground surface there exist magnetic anomalies (geo pathogenic) zones with different physical characteristics in comparison to "standard" $[6,7,66]$. Figuratively speaking, one can call them "acupuncture" points of the earth, because they (similar to acupuncture points) are areas with altered geophysical parameters (the geomagnetic field, the electrical conductivity of the soil, the electric potential of the atmosphere, the level of radioactivity, etc.). The role of this factor has not been studied completely, although it is considered [9, $56]$, that it might become one of the additional conditions of the human state electromagnetic modification (generating of stress reactions responses).

The influence of Earth's magnetic field fluctuations on heart rate can be illustrated by the results, we obtained during the transatlantic voyage "Ukraine-Antarctica" [37-38]. As singled out, the magnetic field fluctuations determine similar changes in heart rate, the dynamics of which in its turn characterizes the balance of the autonomic nervous regulation of the cardiovascular system state.

In this article, we are not going to consider in detail the extensive factual material about the influence of non-polarized electromagnetic microwave range of the physiological mechanisms of subsequent reactions at the molecular, cellular, organ and system levels. Works by ND Devyatkov, MB Galant [8] YuPLimansky (1990) [50], Y. Khurgin, IV Rodshtat, DS Chyarnavsky,
AS Efimov and SP Sitko (1993), SI Gerashchenko [14] IZ Samosyuk et al. (1999) [73] found out that even inadequate for organism electromagnetic waves transmit to the body information about the rhythms of electromagnetic field. This refers to the millimeter range (frequency, intensity, etc.), with which people coexist only a few dozen years. Its normalization is a precondition for the subsequent recovery of the function and structure of individual cells and the organism as a whole. The transmitter of the electromagnetic field parameters to molecules and cells are most likely water molecules and polypeptides (cytomedines) as the main factors of intercellular interactions.

Enough data has been accumulated on the effect of laser radiation at different wavelengths $[39,40,61$, 70], which is characterized by a narrower therapeutic strip, bordering with destructive effects (depending on the time of exposure, power, absorption). Nevertheless, the low-energy laser light having a luxf density of $0.1-1 \mathrm{~W} / \mathrm{cm}^{2}$ causes photochemical reactions: bio stimulation at the expense of photo induction (influence on cell membranes, activation of cellular metabolism, DNA synthesis, RNA, singlet oxygen formation, etc.) $[4,12,15,26]$. Bio resonant effect $[14,61,78]$, which is the leading in complex reactions in response to exogenous electromagnetic vibration, is achieved by empiric selection of shape and frequency of electromagnetic oscillations. The authors believe that the physiological homeostasis is achieved in the result of physiological frequency spectrum increase and maintenance of the relative timing of the various wave processes. Modern views on the physiological mechanisms of electromagnetic waves action you may found in [51, 54].

Influence of physical factors, having an electromagnetic component (extreme temperatures, magnetic and electromagnetic fields, microwave, light), on biological structures are largely focused on the cell nucleus [76]. According to AS Derdi [75] and VGShahbazov [76] molecular complexes that make up the system of the cell nucleus, function in a living cell at "biological" temperature as a kind micro oscillators. They convert the energy of the thermal vibrations of the water dipoles into electric charge of the nucleus and electromagnetic radiation in a wide frequency range within the cell and beyond. This energy generator provides many cellular functions, including cytoplasmic transport of substances, their exchange and inheritance implementation. The maximum development, from our point of view, this mechanism reached in deep phosphorescent fish, stingrays, eels, etc. Bioluminescence can be regarded as evolutionary hypertrophic generating property (biosynthesis) and transport of electromagnetic waves to compensate the lack, which occurs in underwater environmental medium.

There are three types of electromagnetic relationships (electromagnetic control) in the body - nervous regulation (the relationship of the central control system with the peripheral executive receptor elements), 
autonomous connections between elements (cells and macromolecules) and signals, given by the control system to all the elements at the same time [68]. We assume the presence of signaling schemes of the central nervous system of the type "to all-over": in the peripheral ganglia, the endocrine glands are "receivers" that are configured on the "emergency" rate, and provide signals retranslation to the actuators at the corresponding frequencies.

\section{Regulation of electromagnetic endoecology}

Therefore, by now, there are accumulated enough data for credible approval of the existing dependence of highly organized living beings (as unions of atoms and molecules), including humans, on electromagnetic background of Earth. Electromagnetic waves, changing the fullness of electromagnetic energy of the body frame (Fig. 2), evoke the appropriate resonances and fluctuations of the electrical potential in its molecular structures, participate in functions ` control and ensure the electromagnetic homeostasis maintenance (equilibrium). Excess of reactions on waves ' physical characteristics (intensity, shape, frequency, length, etc.) above physiologically required level lead to incoordination of nervous, immune and hormonal regulation.

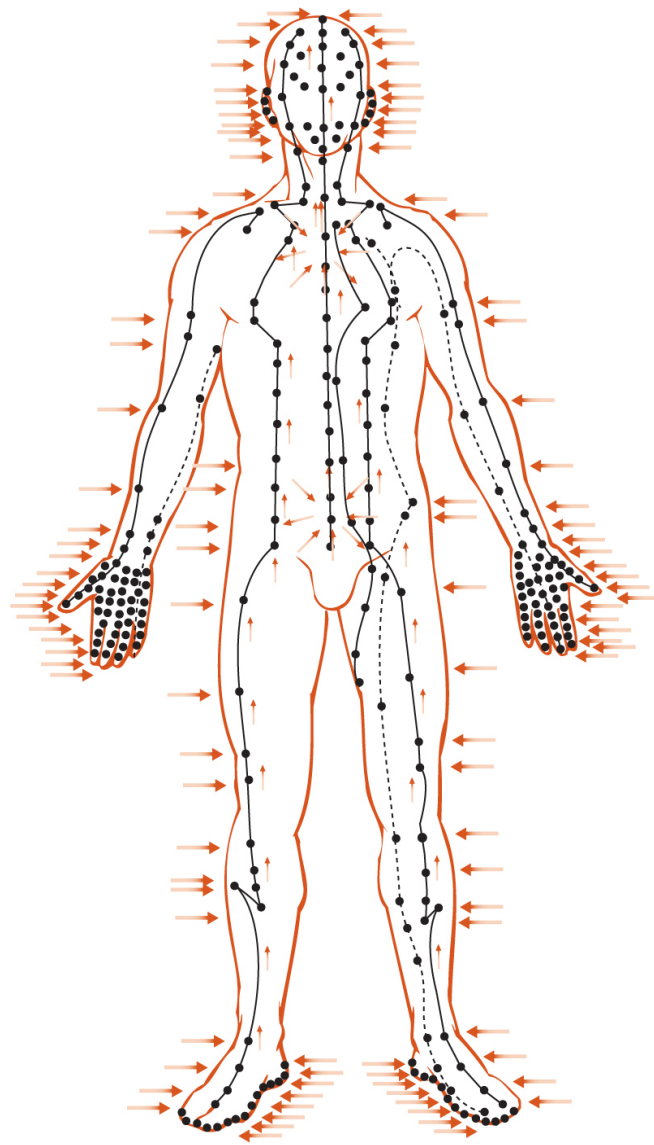

Fig. 2. Electromagnetic skeleton of the body, defined by a lightweight electromagnetic conductivity:

Ears, hands, feet are zones of high concentration of electromagnetic receptors (acupuncture points)
In fact, it is possible, with certain assumptions, to imagine the existence of a separate functional system that regulate electromagnetic balance of the body (FSREB) [27-31], containing all the ingredients of a classic functional system, according to PK Anokhin [1].

The hypothesis of the possible existence of "ecoceptiv sensitivity" suggested by YuPLimansky, meaning its ability to monitor changes of the environmental factors (electric, magnetic fields, etc.) which do not carry information that requires immediate sensory signal [50]. Functional systems of the body are formed up of dynamically mobilized structures in the scale of the whole organism, and on their activities and the result does not reflect the exceptional impact some type of the involved anatomical structures. Moreover, the components of particular anatomical accessory are mobilized and involved in their assistance to obtain programmed result. According to the interaction principle, they are combined to achieve any adaptive result, for example, stabilization of blood pressure in the circulatory system, nervous and endocrine systems. Therefore, at systematic approach, we focus not on some anatomical feature of one component involved, but on the principles of many components organization from many anatomical systems with indispensable result of this extensive system activity [1]. The structure of the functional system of electromagnetic regulation based on the above factual material of light therapy, the example shown in Fig. 3. From our point of view, workability of such a system will depend on the quality of the external electromagnetic flux (biologically adequate wavelength range, polarization, presence of evolutionarily developed mechanisms for utilization).

As shown in Fig. 3, starting stimulus in the form of polarized electromagnetic waves within the optical range of constant magnetic field, radiation in the infrared or millimeter wave bands, as well as invasive mechanical irritation (needle stick) cause activation of poly modal (electromagnetic sensitive) receptors, i.e., acupuncture points. Transmission of electromagnetic signal is carried out through the best ways of their conductivity (meridians and connective tissue stroma). In addition, there are processes of molecular photoreception described separately [29, 52, 54]. Stimulated by electromagnetic signals, neural structures and electro dependent processes stimulate "decision taking" and determine the result of the acceptor action (visceral organ). As recipients can be considered organs, that experience electromagnetic imbalance due to the excess of biologically inadequate radiation, suffering from congestion of free radicals (lipid peroxidation), primarily, neural hormonal and immune regulatory system. Their functional state, after electromagnetic exposure, determines the (positive or negative) feedback, that is changes in electromagnetic conductivity of acupuncture points. Such self-regulation (harmonization of the existing energy background with the demanded) extend on the amount of energy absorption, regulated 


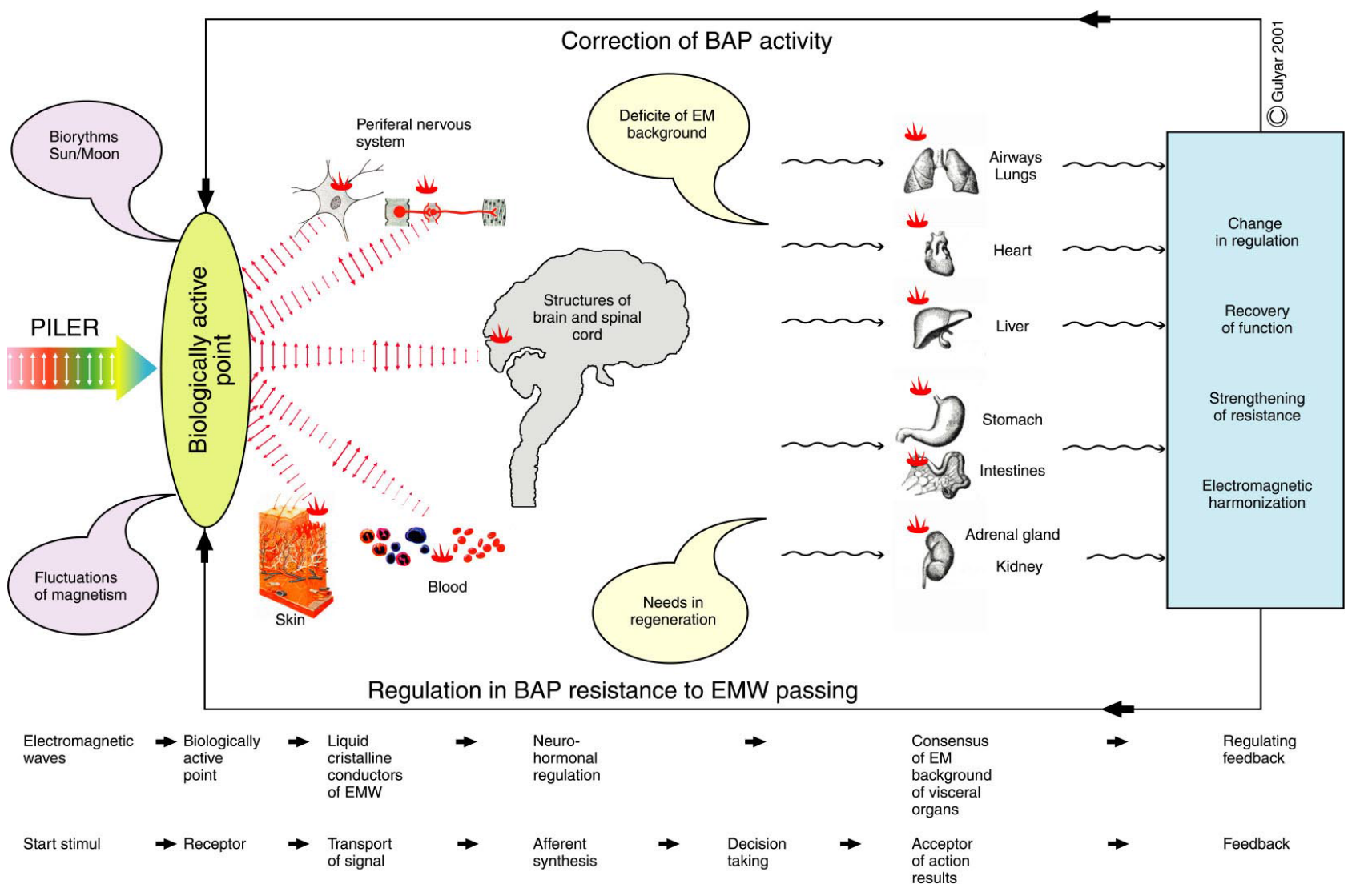

Fig. 3.General cheme of functional system of electromagnetic balance regulation

by the structures that provide electromagnetic reception. This process also depends on geomagnetic, solar and lunar activity.

It is important to mention the significance of polarized electromagnetic waves, as their polarization is the main factor causing a stable biological effect.

It should be noted that the above given scheme should be regarded as a working hypothesis, as some of its units do not yet have sound anatomical and physiological characteristics. However, in recently completed (2002) anatomical studies [49], there was performed the identification of acupuncture points on the upper limb by sonication showed their $80 \%$ coincidence with interstitial connective tissue formations (inter muscular, extending along the surface and into depth). The authors concluded that the meridians can be treated as a structure consisting of connective tissue that connect the superficial and deep formation, participating in the transfer of biophysical changes occurring under the action of the needle. There are also detailed anatomical data showing the connection of the nerve structures and acupuncture points. There are found anatomical correlates (mostly nerve trunks) of 24 primaries, 28 secondary, 27 tertiary and 31 non-specific acupuncture points. We carried out identification of 110 points in two hundred subjects [10]. This is meningful for understanding the integrative role of interstitial tissue in providing physiological effects distantly arising at acupuncture. Research of biologically active zones relations to the surface of the human body allowed to allocate zones with "wave representation" of individual organs [45-46].

On the other hand, by biophysical modeling method [78] we established physical grounds of the existence of coherent electromagnetic field of the body ("electromagnetic framework") in the millimeter range. There are four groups of facts, which convince the author. First of all, a pronounced presence of the electric fields intensity in cell membranes (about $10^{-5} \mathrm{~V} / \mathrm{cm}$ ), which is created due to through membrane ion transport. Second, frequency of the cell membranes oscillation, determined by their mechanical properties, lies within the range of $10^{10}-10^{11} \mathrm{~Hz}$. Third, the presence of skin, separating regions with different refractive indices, separates the inner area with a large refractive index, which supports more intensive radiation density at the expense of internal reflection. The fourth factor, which conditions a possibility of a coherent field, is the identity of the genome of all somatic cells of a particular organism. They can be regarded as active centers providing genome transformation into a spectrum of electromagnetic radiation. From the standpoint of the calculation of limited cycles, we showed that the meridians are (functionally) coherent running electromagnetic wave. Wave conductor properties of meridians define their internal transport in accordance with the laws of nonlinear optics for a closed resonator filled with nonlinearly absorbing medium with active 
centers. Minimum of losses is determined by the fact that the angles of waves that falls on the inner surface of the skin should be less than the angle of the total internal reflection for the environment. A direct experimental proof of the electromagnetic nature of the meridians is registration by the authors of a non-equilibrium component of electromagnetic radiation of the organism in mm-range. The complex of equipment with its inner noise level for the frequency range within $53-78 \mathrm{GHz}$ in the region $5 \cdot 10^{-23} \mathrm{~W} / \mathrm{Hz} \cdot \mathrm{cm}^{2}$ allowed to register radiation areas of the human body and its dynamics in the $\mathrm{mm}$ range. The value of the non-equilibrium component (radiation from the biologically active zones) varied in the range of $10^{-23}-10^{-21} \mathrm{~W} / \mathrm{Hz} \cdot \mathrm{cm}^{2}$

In addition, the proven clinical efficacy of PILER-light also gives grounds to confirm the hypothesis mentioned above, and it is important to determine the future direction of its deep studies of individual units. For example, the "narrow" places, which will require urgent investigation, in our opinion, are the features of electromagnetic signals transport into connective tissue and the process of transmission them into nerve structure. It is important to pay attention to photo dependent processes at the level of cellular membranes and organelles, which should have a particular response to electromagnetic waves of optical range. The influence of electromagnetic and contribution factor may be the basis for clarifying biophysical mechanisms of many electro dependent processes in cells and their systems.

The main indicator of the FSREB activity, which can be determined indirectly, is the quality of the internal organs functioning and visceral systems in general. It depends on the nature of the source of the organ electromagnetic background or features of external action, which are the resulting of wavelengths, their power and exposure. From the available empirical observations, we can say that there is a natural self-regulation mechanism of the circulating volume of electromagnetic energy. For example, from clinical practice it follows that at different times of the day there is a different activity of the acupuncture points as the receptors, which receive electromagnetic waves. This is attributed to sun exposure and biorhythms (depending on the phase state of the Sun and the Moon). At daylight, when we observe a high level of electromagnetic energy falling on the surface of the body, many acupuncture points are "closed" (become less susceptible to excess energy), in the dark - "open." Moreover, at diseases followed by increased peroxide oxidation (which usually happens) in the respective systems of visceral tissue there increases metabolism and power consumption, there appears an energy deficit. At the same acupuncture points, "responsible" for the particular organ or segmental area, "open", and become strongly susceptible to electromagnetic factors up to respond to mechanical stimulation. At this time, these points become sensitive and you can easily determinethem on your body.
From the standpoint of light puncture, it becomes clear and understandable the existence of areas with a high concentration of biologically active points on the body (face, ears, hands, feet) as the sites that in the process of evolution has always been open to solar (light) electromagnetic waves (unlike protected by fur or clothing). Alongside, it is observed a general biological principle of multiple redundancy (backup) in case of traumatic injury of one of their sites.

The above hypothesis of the FSREB explains the non-correspondence between the anatomical and functional efficiency of "meridians" or "channels" concept in terms of oriental medicine [62]. In accordance with this approach, the system of acupuncture points, "meridians", as well as permanent and variable electromagnetic fields of the human body interact with the holistic system of liquid crystal fibers of collagen, which is the basis of connective tissue.

On the effectiveness of the considered working FSREB hypothesis may also indicate the effectiveness of BIOPTRON-color therapy method, which is based on the influence of electromagnetic waves of different lengths on biologically active zones (points) [3].

We should say that the existence of a system that regulates relations between the body and the external electromagnetic field with more or less empiricy is always under consideration. In particular, R Becker [2] described a "slow electromagnetic system of regulation in vertebrates", which is associated with a peculiar distribution of the surface potential (Fig. 4). The author presents evidence that this system controls the speed of electrical impulses extension in nerves, transmits to CNS information associated with pain and mental functions. He suggests that this system controls the general behavior of animals and that through it is carried out the influence of the magnetic and electric fields of Earth on animals and humans [69].
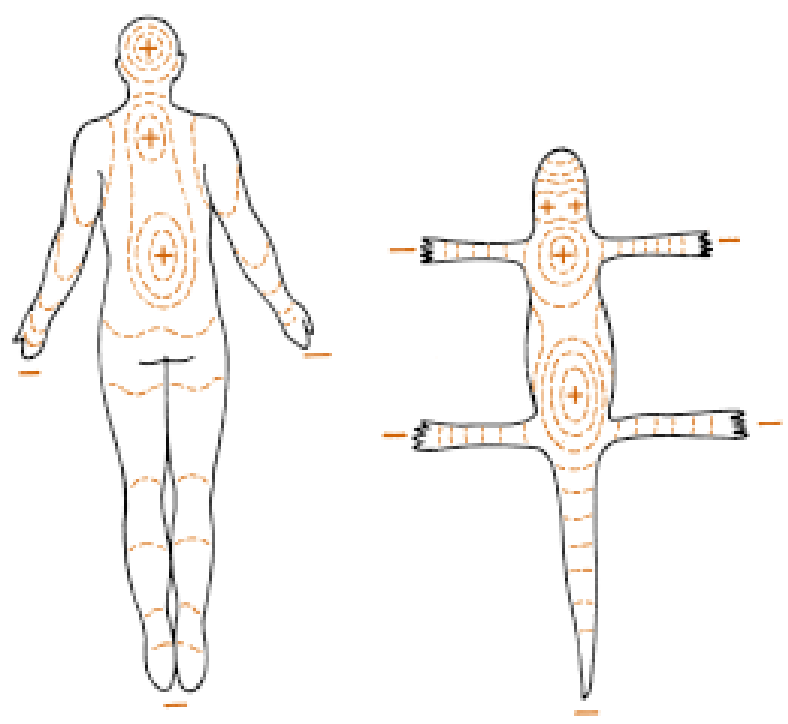

Fig. 4. Distribution of surface electric potential on the human body and lizards [65] 
An interesting approach of VGMakats et al. [58] is based on measurements of the electrical conductivity of biologically active zones. There are revealed the interdependent self-functioning energy cycles, especially the regulation of vegetative homeostasis and the interaction between the individual functional systems of the body. This allowed the authors to put forward the idea of the existence of "functional-energy system of biological objects (Makats effects)."

Violations of the harmony of the electromagnetic interactions of the external and internal environment determine the occurrence of various types of pathology. The resulting deformation of this body's electromagnetic field can be recorded using Kirlian effect [47]. Modern methods of the human body electromagnetic radiation measurement in mm range is already allow to detect the presence of a non-equilibrium component [78], i.e., "Aura" that characterizes the individual peculiarities of the body functional state (Fig. 5).

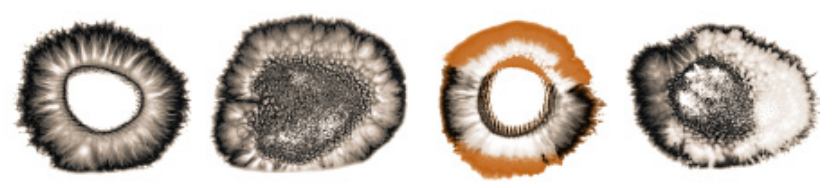

Fig. 5.Plant bio field reaction in response to the impact of human bio-field [77]:

A - human generation thoughts of love and kindness to the plant;

B - plant responses to positive "emotions"; V - generation of human thought "I'll cut you";

$\mathrm{T}$ - plant responses to negative "emotions"

\section{Electromagnetic exoecology and its significance for the organism}

Let us consider the relationship of organism with the environment from a position of "usefulness" of certain types of electromagnetic waves. Urbanization, a companion of life in the modern world gives rise to many electromagnetic wavelengths not found in the evolution. When applied to the "usual" waves, for example, solar spectrum, we can talk about a possibility of specific adaptation (accumulation of melanin in the skin of Africans, blond color for northerners, etc.) and non-specific neuro hormonal activation of antioxidant system to block lipid peroxidation. Then for historically "new" influences, there are observed different and usually negative variety of responses. Generally recognized term "electromagnetic pollution" (electromagnetic smog) indicates patterns of adverse effects of the electromagnetic field increasing with exposure and frequency characteristics. The greatest amount of information is available about the biological effects of microwaves, which is expressed in the disorder of the central nervous system, followed by dysfunction of visceral systems up to the heating (destructive) effect.
The consequences of an adverse effect on the organism of environmental factors can largely be reduced to common resulting pathophysiological mechanisms. It can be described as an overload of the antioxidant system, forced to neutralize the excess of free radicals generated by both external and internal environments. The final process is the increase in lipid peroxidation (oxidative stress), during which there occurs destruction of cell membrane lipids, enzymes, disintegration of regulatory influences, mutagenicity increased and other negative phenomena, which ultimately determine sickness rate and life expectancy (Table 1).

Table 1

Two leading complexes of environmental factors that determine the state of health

\begin{tabular}{|c|c|}
\hline $\begin{array}{c}\text { ENVIRONMENTAL } \\
\text { (PEROXIDATION) } \\
\text { STRESS }\end{array}$ & ELECTROMAGNETIC \\
MISBALANCE \\
\hline FREE RADICAL & INSUFFICIENCY OF \\
INTOXICATION & BIOLOGICALLY DEMANDED \\
& RANGE EM WAVES \\
ENHANCING & EXCESS DISRUPT RANGE EM \\
PEROXIDATION & WAVES \\
\hline
\end{tabular}

A second, less studied, but not less important aspect of determining the state of health is the maintenance of normal background levels of electromagnetic stimulation of biochemical and biophysical processes. The example of the difference in the quality of plants growth, grown in the basement and in the sunlight, once again convinced of the need to provide every earth living being with insolation, the intensity of which cannot be below a certain critical value. However, the electromagnetic imbalance, everywhere overtaking each of the members of a modern society, give evidence of isufficient obtain, by many of them, of electromagnetic waves of necessary biologically range (insolation), and an excess of the action of destructive electromagnetic influences. In fact, we speak of substitution for the body of one wavelength for another, which "taking" a somebody else place (ecological niche) "parasitize" (causing physiologically inappropriate resonant and thermal effects) and bring destabilization where cellular structures are waiting for natural (due) wave.

These technogenic electromagnetic fields have a simpler frequency organization and pulse structure; however, they have several orders of magnitude greater intensity and uneven localization in space [62]. As damaging electromagnetic waves are in uncontrollable excess, the list of adverse effects is hard to predict, but in any case, these changes could become irreversible.

The significance of the new urbanized electromagnetic environment at home is very important. According to measurements carried out at the Institute of Terrestrial Magnetism and Radio Wave Extension [71], "a characteristic tension on the surface of the human body varies from 20 to $200 \mathrm{~V} / \mathrm{m}$, reaching on top of $1000 \mathrm{~V} / \mathrm{m}$. Wearing natural clothing gives almost no 
effect on these statements. Clothing made of synthetic materials when it is removed, or natural movements creates strength values up to $14,000 \mathrm{~V} / \mathrm{m}$, contributing to the development of cardiac arrhythmias. The same refers to shoes made of synthetic materials - the sole while in contact with asphalt, at each step, generates a voltage of $10-20 \mathrm{kV}$. With small dimensions of standard flats and excess of furniture in them of non-natural materials, surrounded by wiring each dwelling turns into a ball of electromagnetic fields, each protrusion of furniture - in the storage of kilovolt static charges. Friction of tires on the asphalt turns a moving car in a good capacitor".

From this non-equilibrium state there can be only two alternatives: the first - leaving the radiation zone, reducing the length of stay or screening (with attenuation coefficient over 2 growing shortage of natural electromagnetic background, followed by a deterioration of health [71]); and second - restoration of the volume of the incoming electromagnetic waves solar spectrum. Natural illustration of the above can be considered as the situation with the winter-spring morbidity and efficiency improvement of the summer. Indicative data, obtained during the survey of the population of different regions of Ukraine [18, 19]. Let us consider in more detail the main groups of mentioned electromagnetic influences (Table 2).

As you can see, natural capabilities that compensate electromagnetic waves of solar spectrum are limited and the only adequate alternative is polychromatic polarized (PILER) light. Accordingly, the device BIOPTRON as its generator represents an additional opportunity to align the electromagnetic balance.

The range of sun doses influence fluctuations in terrestrial conditions is very broad, and they vary depending on the different circumstances (Table 3). It is significant that an overdose of sun exposure mostly accompanied by an increased dose of its ultraviolet and infrared parts, and its lack reveals in a decrease of the visible portion of the solar spectrum. It should also be noted that even the small part of the sunlight that reaches the Earth's surface in polarized form, under the influence of industrial dust or smog, is depolarized and loses biological effectiveness.

\section{Main mechanisms and the concept of PILER-light therapy}

From these data it follows that general indications for correction of the electromagnetic imbalance can be called a disorder associated with electromagnetic lack, overload by "parasitic" electromagnetic waves and free radicals. BIOPTRON-PILER-light therapy method is the most appropriate to provide the most physiological way of electromagnetic harmony recovery at all levels of the organism - from molecular to systemic.

While the direct impact on the biological substrate of electromagnetic waves of the visible spectrum there occurs a direct energy replenishment of the electron orbits components and transition of electrons to higher levels, which increases the chemical activity of atoms.

Redistribution intermolecular energy leads to modification of the molecule, which defines a more pronounced stabilization of its structure. Restoration of the structure portions of cell membranes by electromagnetic reconfiguration of molecules increases the membrane potential and its ability to resist the action of free radicals. Especially effective action, PILER-light manifested in case of electromagnetic imbalance that defines the subsequent leveling therapeutic effect. Here reveals biophysical aspect of the PILER-light antioxidant effect.

This process prevents the progress of other, less favorable changes occurring under the influence of electromagnetic wave of other lengths (ultraviolet, infrared, microwave, etc.), manifested in the strengthening of intermolecular oscillatory processes, heating and breaking of intermolecular bonds.

Manifestations of the general mechanism of PILER-light action will not be the same depending on the regional properties of the perceiving surface area of the skin. The process described above takes place in all cases of direct (local) impact. However, if in a zone of light application gets a biologically active (acupuncture) point, there turns on the mechanism of "lightweight" entering of biologically necessary electromagnetic energy range and its subsequent transport to customers located in the electromagnetic "frame." Thus, there appears a possibility of systemic influence on organs distant from the application site. This principle is the basis for BIOPTRON color therapy technology as a painkiller and visceral system correcter.

PILER-light due to its polarization has better penetration ability compared to non-polarized electromagnetic waves. This opens up another useful chain connected with direct influence on the cells and plasma of blood passing through the capillaries of the skin.

Restoring of their function ensures, on the one hand, strengthening of the structure of erythrocyte membranes and extending the active life period of red blood cells in the bloodstream, and on the other hand - activation of leukocytes and lymphocytes function - immune proteins production, increase of phagocytosis, etc. [65, 72]. It is typical, that at almost any light application capillary network is automatically covered within the illuminated area and, accordingly, the immune normalizing mechanism starts to work, which is extremely important for practical medicine.

Currently known mechanisms of polarized light action are actually aimed at slowing down the natural process (apoptosis) or induced (necrosis), destruction of cellular functions, i.e. breaking the process of cell death.

The PILER-light therapy concept, in modern sense, consists in combined application of local and systemic effects of polarized electromagnetic waves of 
Types of electromagnetic influences

Table 2

\begin{tabular}{|c|c|c|}
\hline DESTROYING & DESTABILIZING & REGENERATIVE \\
\hline $\begin{array}{l}: \text { Cosmic rays } \\
: \text { Abandant solar } \\
\text { Activity } \\
: \text { Gamma rays } \\
: \text { X-rays } \\
: \text { UV rays } \\
: \text { IR rays } \\
: \text { Microwaves } \\
\text { (more than } 1 \mathrm{~mW} / \mathrm{cm}^{2} \text { ) } \\
\text { : LAZER-light } \\
\text { (high energy) } \\
: \text { Ultrasound }\end{array}$ & 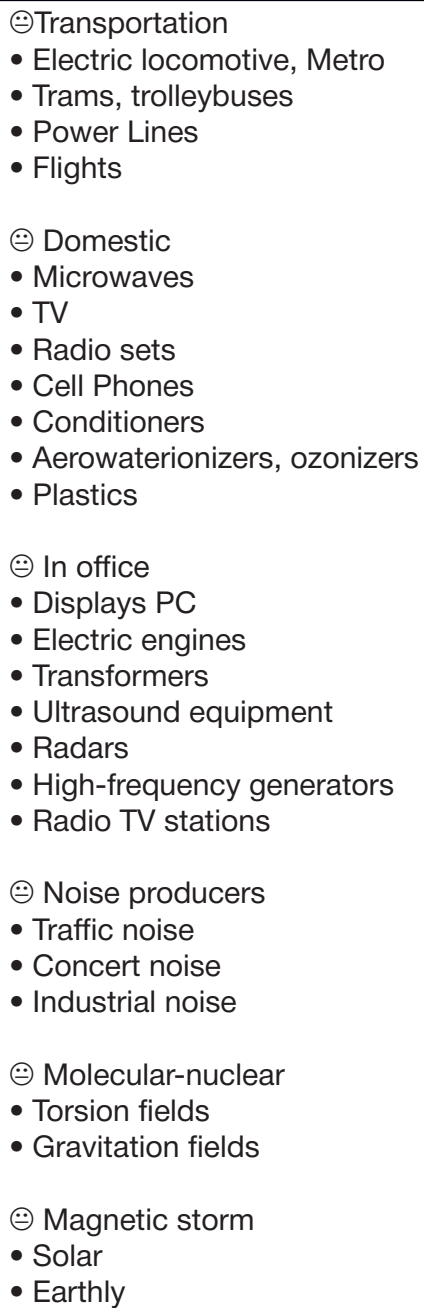 & $\begin{array}{l}\text { :) PILER-light } \\
\text { (polychromatic, } 95 \% \text { of } \\
\text { polarization, low-energy) } \\
\text { (:) Sunlight } \\
\text { (polychromatic, up to } 3 \% \\
\text { of polarization) } \\
\text { (:) LASER-light } \\
\text { (monochromatic, } \\
\text { polarized, low-energy) } \\
\text { (-)Mikrowaves } \\
\text { (Nonpolarized, less than } \\
1 \text { mW/cm²) } \\
\text { :-) LED-light } \\
\text { (monochromatic, non } \\
\text { polarized, low-energy) }\end{array}$ \\
\hline
\end{tabular}

Reasons for the solar electromagneticdisharmony

\begin{tabular}{|c|c|}
\hline NATURAL & ARTIFICIAL \\
\hline \multicolumn{2}{|c|}{ OVEREXPOSURE } \\
\hline $\begin{array}{l}\text { Mountain conditions } \\
\text { Recession of ozone layer } \\
\text { Solar atmospheric magnetic storms } \\
\text { Polar (summer) day }\end{array}$ & $\begin{array}{l}\text { Many hours of work in the sun } \\
\text { Sun overdose } \\
\text { Overexposure to the sun/snow in the mountains } \\
\text { Solarium overdoze exposure } \\
\text { Electric welding }\end{array}$ \\
\hline \multicolumn{2}{|c|}{ DEFICIENCY EXPOSURE } \\
\hline $\begin{array}{l}\text { Atmosphere polution } \\
\text { Long dense cloudiness } \\
\text { Magnet atmosphere anomalies } \\
\text { Polar (winter) night }\end{array}$ & $\begin{array}{l}\text { Stay in low light premises } \\
\text { Stay in screened rooms, transport, marine and } \\
\text { submarine vessels } \\
\text { Work in mines, workshops, basements, hyperbaric } \\
\text { chambers } \\
\text { Distorted sunlight structure by glass, light filters }\end{array}$ \\
\hline
\end{tabular}


biologically necessary (solar) range, using specialized sensory receptor or sensory entrance gates, liquid-crystal conductors and all the connective framework for electromagnetic energy transport to regulatory system or areas, experiencing its deficit or imbalance.

In case of PILER-light therapy prescription, it is important to know the mechanisms of action of polarized light and clearly determine the feasibility of its aplication. It is helpful to understand the PILER-light therapy-leading role in a complex antioxidant Zepter technology (simultaneous use). Enhancing of the effect in this case is provided by unidirectional (peroxide oxidation-reduction), correction of various components of antioxidant balance [20]. The point of application and the level of biochemical or electromagnetic antioxidant protection, in each case, are not the same - from the cell membrane to the systemic organ that creates a multi-level and wider coverage for such electromagnetic disharmonies protection.

\section{Achievements and prospects of PILER-light therapy technologies}

Start of the 3rd millennium for light therapy, as for physical therapy technique in a broad sense, is characterized by "warming" of" classical" medicine attitude and successful search of cooperation with experts applying "non-traditional" approaches. This is due to accumulation of objective information about the mechanisms of the physical factors action for specific medical purposes, the expansion of the devices ' features and transition to a new level of computer processing and evaluation of facts.New methodological possibilities defined reassessment of the existing provisions and allowed to provide greater depth of the facts analysis. The gulf reduced between "fundamental" and "applied" researches, which in fact, under the new conditions of the Ukrainian science existence, have grown finally together in a comprehensive system to obtain reliable scientific facts, introduce them into clinical disciplines and rece timely feedback on the medico-social "order" for new research. In this sense, light therapy occured in a pole position. On the one hand, in due time, there appeared a new generation of light therapy equipment, sophisticated Bioptron device, on the other - thanks to open to independent research policy of Zepter Company, it has become real in Ukraine to do theoretical and clinical research, with the ultimate aim to create better opportunities for health correction and improve quality of life. Contribution to the fast track of light therapy technology development has made public understanding of the rapidly of negativ "parasitic" electromagnetic background growing, which increased its demand [12, $17,25,26,41,43,64,65,74,80]$.

The greater the accumulated knowledge of physical therapy techniques, the more visible they are incomplete. Clinical needs and expectations of users require for Advanced Studies of increasing complexity and depth of analysis. Clarification of the PILER-light mechanisms of action has not changed its clinical efficiecy, but the list of diseases and premorbid disorders got a trend to decrease, which reflects improvement in the quality of care. A number of myths, caused by primary enthusiasm and unexplained effects, gradually disappear, it is replaced by a sober list of indications that distinguishes a professional approach. However, the technology remains to be designed for a wide user, preferably having BIOPTRON at his own home. The task of the researcher continues to remain bidirectional - deeply investigate undisclosed facets of the technology and to provide specific modes for practical application. Status of knowledge about the basic issues of solved and unsolved light therapy technologies, which appeared to date, are presented in Table 4.

Thus, at present, questions of legal and medical legalization of light and color therapy can be considered as resolved. There are defined the basic mechanisms of PILER-light action and a set of indications for applications.It is developed the first generation of therapeutic regimes and color therapeutic programs.

BIOPTRON: solved and unsolved questions

Table 4

\begin{tabular}{|c|c|}
\hline SETTLED SOLVED & FOR DECISION \\
\hline $\begin{array}{c}\text { Full medical and legal authorization of BIOPTRON } \\
\text { devices }\end{array}$ & $\begin{array}{c}\text { Updating of the list of diseases for which light therapy is } \\
\text { effective }\end{array}$ \\
\hline $\begin{array}{c}\text { The main mechanisms of PILER-light action are } \\
\text { defined }\end{array}$ & $\begin{array}{c}\text { Detailization of physiological and pathophysiological } \\
\text { mechanisms of PILER-light action }\end{array}$ \\
\hline $\begin{array}{c}\text { The basic therapeutic areas are described } \\
\text { correction }\end{array}$ & $\begin{array}{c}\text { Search for the new aspects of the therapeutic, restorative } \\
\text { and preventive application of PILER-light }\end{array}$ \\
\hline $\begin{array}{c}\text { It created the first generation color therapy treatment } \\
\text { and rehabilitation programs }\end{array}$ & $\begin{array}{c}\text { Implementation of color therapy programs and creation of } \\
\text { their new modifications }\end{array}$ \\
\hline $\begin{array}{c}\text { Initial introduction of the population of the possibility } \\
\text { of Bioptron light therapy }\end{array}$ & Full coverage (each family) by light and color therapy \\
technologies
\end{tabular}


In recent years, attention has been paid to a new nano filter containing fullerene (the fourth form of carbon state, molecular, $\mathrm{C}_{60}$ ) [81]. It is able at the nano level to change the properties of the light passing through it. Accordingly, such light can acquire additional properties [82].

They arise due to the fact that the carbon atoms entering into the $\mathrm{C}_{60}$ molecule can influence the trajectory of the transmitted light quanta by its own electromagnetic oscillations, which obey the icosahedral symmetry of the shell. Rotating at speed of $1.8 \cdot 10^{10} \mathrm{~s}^{-1}$, the spatial network of carbon atoms entering the $\mathrm{C}_{60}$ molecule, in accordance with the Fibonacci distribution law $\left(\Phi^{2}+\phi^{2}=3\right)$, additionally redistributes the light electromagnetic flux. Such a modification of the light flux was called "hyperpolarization". When light passes through a fullerene material $2 \mathrm{~mm}$ thick $\left(10^{6}\right.$ layers of $\mathrm{C}_{60}$ molecules), there occur changes $10^{18}$ in the direction of the motion of quanta. Taking into account the rotation of the $\mathrm{C}_{60}$ molecule, a new, more ordered spiral configuration of their flow (Tesla toroids) is eventually created. The symmetry of the flux of quanta obtained in this way should create harmonizing possibilities for more efficient absorption of each of the passing quanta [82-84].

It was experimentally established $[85,86]$, that a 10-minute application to the inflammation locus or to E-36 acupuncture point of fullerene light caused in animals a significant reduction of pain. Analgesia was 43.5 and $38.5 \%$, respectively. All non-painful behavioral reactions increased their duration. Duration of sleep compared with the control increased twice (application of light to the locus of inflammation) and 3 times (application to acupuncture point E-36).

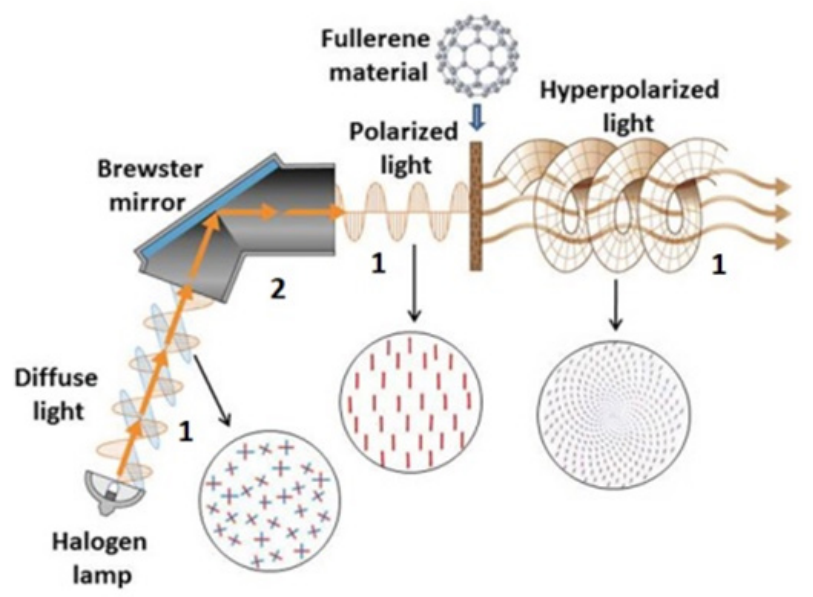

Fig. 6. Scheme of converting diffuse light into vertically linearly polarized and hyperpolarized [19, 83, 84]:

1 - scheme of oscillations of vectors of light

electromagnetic waves, 2 - Brewster polarizer of the BIOPTRON device.

Differences in the vector structure of the light fluxes are shown separately (circled).
Comparison of these data with the results obtained for monochromatic polarized light ranges showed that they could be attributed to the most effective group of analgesic light factors. Fullerene light, along with analgesic, have a powerful sedative effect, surpassing effects in comparison with all other ranges of polarized light.

So, the new fact is that polarized polychromatic light of the BIOPTRON device, which has passed through a nano photonic fullerene filter, acting onto the pain or acupuncture point E-36, significantly reduces pain and has a sedative effect.

\section{Conclusion}

Presented analytical material comprises a working concept of light therapy based on modern views of the relationship between electromagnetic factors with a living organism. It is based on the use of acupuncture points for the biologically necessary electromagnetic waves to enter the system (frame) of the conductors and consideration the electromagnetic framework as a means of light range polarized electromagnetic waves transport. Their zones-recipient may be considered organs that endure electromagnetic imbalance due to the excess of biologically inadequate radiation, suffering from free radicals' congestion (peroxidation) - neuro hormonal and immune regulatory systems of the organism to a greater or lesser extent related to biologically active periphery. Subsequent stimulation or modification of functions of the recipient zones determines the achievements of useful therapeutic effect, combination of which with local reparative processes, derived from direct exposure, allows to achieve the clinical purpose. The results of targeted experimental studies and clinical experience that gradually accumulate, will refine or change some of the positions that will give an impetus to the further improvement of the light therapy technology, and perhaps will give a qualitative leap.

The light therapy success now requires coordination of professionals ' having experience in the field, systemic discussions, regular publication of the experimental results and clinical studies, significant efforts to extend information among managers and users, corresponding lecture activity.

BIOPTRON-light therapy is a new and promising direction for a wide range of specialists, from representatives of theoretical medicine to clinicians and practitioners (beauticians, chiropractors, etc.). Studies in these new directions will always remain rewarding, as the expansion of knowledge of concrete members and associates defines the achievement of a new quality of health medical support, the pursuit of which is humane and honorable task of everyone.

The author will consider the goal reached in case of a significant appearance of interest to issues of electromagnetic ecology, BIOPTRON light therapy, and as a result, occupation by it a leading position in physical therapy. 


\section{Conclusions}

1. The increase of the adverse electromagnetic background may be an additional cause for non-specific disease growth. The last can be explained by the presence of electromagnetic imbalance and environment-related free radical overloads.

2. Natural options to compensate electromagnetic wave solar spectrum lack is limited, adequate alternative is PILER-light.

3. We put forward the hypothesis of the existence of the body's functional system of electromagnetic balance regulation.

4. Working light therapy concept is based on the possibility of using acupuncture points, the biologically necessary electromagnetic waves, to enter conductors and consideration of this electromagnetic framework as a means of transport. Zones-recipients are named organs experiencing an electromagnetic imbalance due to excess of biologically inadequate radiation, overload by free radicals of neuro hormonal and immune regulatory systems. Subsequent stimulation or modification of functions of zones-recipients determines the achievement of useful therapeutic effect, combination of which with local reparative processes allow to achieve clinical goals.

5 . The modern approach to light therapy is in combined (local and systemic) impact of electromagnetic waves of biologically necessary (light) range.

6. Settled, for the present time, can be considered legal and medical recognition of light color therapy, the basic mechanisms of PILER-light action, a list of indications, and the first generation of therapeutic regimes and color therapy programs.

7. Intensification of light therapy implementation technology is associated with the need to create new treatment programs and to develop color therapy analgesic technologies. We are faced with search and disclosure of PILER-light therapeutic action mechanisms in respect to the visceral systems, studies in biophysics, virology, veterinary medicine, crop and emergency medicine, development of a new generation of light therapy equipment, as well as Zepter antioxidant technologies consolidation.

\section{References}

1. Anokhin PK. Essays on the physiology of functional systems. Moskow: Medicine, 1975; 447 p. (in Russian). Анохин П.К. Очерки по физиологии функциональных систем.- М.: Медицина, 1975.- 447 с.

2. Becker R. The direct current control system. A link between environment and organism.NY State J Med. 1962; 62:1169-80.

3. Bioptron-color therapy. Gulyar SA, editor. Kiev: Zepter,1999; 104 p. (in Russian). Биоптрон-цветотерапия / Рук-во подред. С.А. Гуляра - Киев: Цептер.- 1999.$104 \mathrm{c}$.

4. Bobrova EA. Treatment of osteoarthritis by a helium-neon laser and infrared spectrum - In: Internat.
Scientific-practical conference. Med. rehabilitation, balneology and physiotherapy .-Yalta, 1999; p. 156-157 (in Russian). Боброва Е.А. Лечение остеоартроза методом лазеротерапии гелий-неоновым и инфракрасным спектром - В кн.: Междунар. науч-практ.конф. «Мед. реабилитация, курортология и физиотерапия».- Ялта.1999.- C. 156-157.

5. Bogdanov GB. Nonlinear neuroelektrodinamiks and ekobalancing. Kiev: Univ USKHA, 1991; 406 c. (in Russian). Богданов Г.Б. Нелинейная нейроэлектродинамика и экоуравновешивание.- Киев: Изд-во УСХА, 1991.- 406 с.

6. Bogdanov GB. Eco ties of bio phenomena. Kiev: Ukraine, 1991; 80 p. (in Russian). Богданов Г.В. Экосвязи биофеноменов.- Киев: Информ.-издат. Агентство «Украина», 1991.- 80 c.

7. Bogush DA. Electromagnetic, geo pathogenic radiation and energy. Kiev: Impuls, 1999; 40 p. (in Russian). Богуш Д.А. Электромагнитные, геопатогенные и энергоинформационные излучения // Киев: Импульс, 1999.- $40 \mathrm{c}$

8. Devyatkov ND., Golant MD. Millimeter waves, and their role in vital activity. Moskow : Radio and link. 1991; 61 p. (in Russian). Девятков Н. Д., Голант М. Б. Миллиметровые волны и их роль в процессах жизнедеятельности.- М.: Радио и связь.- 1991.- 61 с.

9. Dubrov AP. Terrestrial radiation and human health. M.: AMF, 1992.- 45 p. (in Russian). Дубров А.П. Земное излучение и здоровъе человека. М.: АИФ, 1992.- 45 c.

10. Dung HC. Anatomical acupuncture. San Antonio, Texas: Antarctic Press, 1997.- 533 p.

11. Dylman VM. Large biological clock (Introduction to Integral Medicine) . M .: Znanie, 1981. 208 p. (in Russian). Дильман В.М. Большие биологические часы (Введение в интегральную медицину).- М.: Знание.- 1981.- 208 с.

12. Dyvocha VA. et al. Study of the of polarized light BIOPTRON device action on the host defenses at lethal viral infection. Antology of light therapy, Proc. Kiev: BIP NAS of Ukraine, 2009. p. 461-469 (in Russian). Дивоча В.А., Микелашвили М.Т., Костева Т.К. Изучение действия поляризованного света аппарата БИОПТРОН на защитные силы при летальной вирусной инфекции // см. наст. сборник, с. 461-469.

13. Fedorov SM., Fedorova VV. Electro magnetic field of milometer diapason influence on cerebral hemodynamics in sick with the initial manifestations of blood circulation lack in brain - In: Intern. Scientific-practical conf. Medical rehabilitation, balneology and physiotherapy. Yalta, 1999. p. 163-164 (ua). Федоров С.М., Федорова В.В. Вплив електромагнітного поля міліметрового діапазону на церебральну гемодинаміку у хворих з початковими проявами недостатності кровообігу мозку - В кн.: Междунар. науч-практ.конф. «Медиц. реабилитация, курортология и физиотерапия».- Ялта, 1999.- С. 163-164.

14. Gerashchenko SI. Fundamentals of therapeutic application of electromagnetic fields of the the microwave range. K iev: Rainbow, 1997. 223 p. (in Russian). Геращенко С.И. Основы лечебного применения электромагнитных полей микроволнового диапазона. К.: Радуга, 1997.- 223 c.

15. Grabostchyner AJ, Korepanov V., Chaifez YB. Quantum therapy in classical cosmetology. Moskow: Milta. 2000. 74 p. (in Russian). Грабощинер А.Я., Корепанов В.И., Хейфец Ю.Б., Шамов В.Б., Пашков Б.А. Квантовая терапия в классической косметологии: Метод. пособие для врачей.- М.: ЗАО Милта-ПКП ГИТ.- 2000.- 74 c.

16. Gulyar SA. Dual technology to maintain health in ecologically unfavorable conditions: PILER-light and antioxidants synergies. In: BIOPTRON theory, clinical perspec- 
tive. Proceedings of the Jubilee. conf. Kiev: Zepter. 1999. p. 6-21 (in Russian). Гуляр C.А. Двойная технология сохранения здоровъя в экологически неблагоприятных условиях: синергизм ПАЙЛЕР-света и антиоксидантов // БИОПТРОН: теория, клиника, перспективы. Материалы юбилейн. конф.- Киев: Цептер.- 1999.- С. 6-21.

17. Gulyar SA. Winter 2000 - Bioptron contribution to winter recreation. Zepter-news. 1999; 8: 18-19 (in Russian). Гуляр С.А. Зима-2000 - вклад Биоптрона в зимнее оздоровление. // Цептер- новости.- 1999.- № 8. - С. 18-19.

18. Gulyar SA. Does Ukraine need BIOPTRON: medical position. Zepter-news. 2000; 10: 18-20 (in Russian). Гуляр C.А. Нужен ли Украине БИОПТРОН: медицинская точка зрения // Цептер- новости.- 2000. № 10.- С. 18-20.

19. Gulyar SA. Medical and physiological rationale for light therapy in Ukraine (according to the regional screening questionnaire). In: Anthology of light therapy, Proc., Kiev: BIP NAS of Ukraine, 2009. p. 112-121 (in Russian). Гуляр С.А. Медико-физиологическое обоснование необходимости светотерапии в Украине (по данным регионального анкетного скриннинга) // Антология светотерапии, ИФБ НАНУ, 2009, с. 112-121.

20. Gulyar SA. Medical and physiological strategy of the company and the role of Zepter BIOPTRON devices in its implementation. In: Anthology of light therapy, Proc., Kiev: BIP NAS of Ukraine, 2009. p. 28-43 (in Russian). Гуляр С.А. Медико-физиологическая стратегия компании Цептер и роль аппаратов БИОПТРОН в ее реализации // Антология светотерапии, ИФБ НАНУ, 2009, с. 28-43.

21. Gulyar SA. BIOPTRON: electromagnetic environment and the organism. Ridna priroda. 2002; 4: 37-41 (in Russian). Гуляр С.А. БИОПТРОН: электромагнитная экология и организм // Рідна природа.- 2002.- № 4.- C. 37-41.

22. Gulyar SA. BIOPTRON project in Ukraine. Zepter News. 2002; 16: 20-23 (in Russian). Гуляр С.А. БИОПТРОНпроект в Украине // Цептер-новости.- 2002.- №16.C. 20-23.

23. Gulyar SA. Concept of the electromagnetic balance of the body and the Environment: the role of BIOPTRON light therapy. In: New technologies - the path to the future. Proc. of studies and development works. Kiev-Donetsk: South-East, 2003; 2: p.108-120 (in Russian). Гуляр C. А. Концепиия электромагнитного баланса организма и окружающей среды: роль БИОПТРОН-светотерапии // В кн.: Новые технологии - путь в будущее. Сб. научных трудов и разработок, вып. 2.- Киев-Донецк: Юго-Восток, 2003.- C. 108-120.

24. Gulyar SA., Limansky YuP, Tamarova ZA. Acupuncture analgesia by BIOPTRON-PILER-light for physiotherapy. In: Internat. scientific practical conf. Medicine, rehabilitation, balneology and physiotherapy. Yalta. 1999. p. 134-135 (in Russian). Гуляр С.А., Лиманский Ю.П., Тамарова 3.А. Акупунктурная анальгезия БИОПТРОНПАЙЛЕР-светом для физиотерапии // Междунар. научпракт. конф. «Медиц. реабилитация, курортология и физиотерапия».- Ялта.- 1999.- С. 134-135.

25. Gulyar SA, Nykula T.D., Kyrylenko E.E., Kyrylenko E.K. Influence of PILER-light on the visceral systems: cardio-renal effects. In: Anthology of light therapy, Proc. Kiev: BIP NAS of Ukraine, 2009. p. 421-429 (in Russian). Гуляр С.А., Никула Т.Д., Кириленко Е.Е., Кириленко Е.К. Влияние ПАЙЛЕР-света на висцеральные системы: кардио-ренальные эффекты // Антология светотерапии, ИФБ НАНУ, 2009, с. 421-429.

26. Gulyar SA, Limansky YP, Tamarova ZA. Pain and BIOPTRON. Kiev: Zepter. 2001; 128 p. (in Russian). Гуляр C.A., Лиманский Ю.П., Тамарова З.А. Боль и БИОПТРОН. Киев: Цептер.- 2001.- 128 c.
27. Gulyar SA, Limansky YP, Tamarova ZA. The functional system of electromagnetic regulation; unsolved questions. In: Materials of the 26th Congress of the Ukrainian physiology society. Vinnitsa, May 28-30, 2002. Physiol. J., 2002; 48(2):21-22 (in Russian). Гуляр С.А., Лиманский Ю.П., Тамарова З.А. Проблема функціональної системи електромагнітної регуляції та невирішені питання ї̈ легалізації. // Матер. 26-го зйзду Українського фізіологічного товариства, Вінниця, 28-30 травня 2002 р.- Фізіол. ж.- 2002.- 48, № 2.- С. 21-22.

28. Gulyar SA, Limansky YP, Tamarova ZA. Using of the functional systems of electromagnetic regulation to correct disorders of visceral systems. Physiol. J. 2002; 48(4):117118 (in Russian). Гуляр С.А., Лиманский Ю.П., Тамарова 3.А., Колпаков І.Є., Богуш Д.А., Сірик О.А. Використання функціональної системи електромагнітної регуляцї̈ для корекції розладів вісцеральних систем // Фізіол. ж.- 2002.48, № 4.- C. 117-118.

29. Gulyar SA, Limansky YP. Functional system of the organism electromagnetic balance regulation: mechanisms of primary reception of electromagnetic waves of optical range. Physiol. J. 2003; 49(2): 35-44 (In Ukrainian). Гуляр С. О., Лимансъкий Ю. П. Функціональна система регуляції електромагнітного балансу організму: механізми первинної рецепції електромагнітних хвиль оптичного діапазону // Фізіол. ж. - 2003. - 49, № 2. - C. 35-44

30. Gulyar SA, Limansky YP. Functional system of regulation of the organism electromagnetic balance. In: Mater. 13th Intern. Conf. Microwave equipment and telecommunication technologies. Sevastopol, 8-12 September. 2003. Sevastopol: Weber, 2003; p. 101-103 (in Russian). Гуляр С.А., Лиманский Ю.П. Функциональная система регуляции электромагнитного баланса организма // Матер. 13-й Междунар. кон. «СВЧ-техника и телекоммуникационные технологии», Севастополь, 8-12 сент. 2003 г.- Севастополь: Вебер, 2003.- С. 101-103.

31. Gulyar SA, Limansky YP,Tamarova ZA, Bogush DA. A functional system of regulation of the electromagnetic balance of the body and the evidence of its activities. In: Mater. 8th Int. Conf. Diagnostic and therapeutic technology in quantum medicine. Donetsk, 2003; p.158-164 (in Russian). Гуляр С.А., Лиманский Ю.П., Тамарова 3.А., Богуи Д.А. Функциональная система регуляции электромагнитного баланса организма и доказательства ее деятельности / Матер. 8-й междунар. конф. «Диагностические и лечебные технологии в квантовой медицине».- Донецк, 2003.- С. 158-164.

32. Gulyar SA, Rudenko IV, The way of impact signal formation on the biological object, neutralization of pathogenic radiation and device for it. Declarative patent of Ukraine, 49253 A. 2002; Bull: 9 (in Russian). Гуляр С.О., Руденко I.В. Спосіб формування сигналу впливу на біологічний об'єкт $i$ нейтралізації патогенних випромінювань і пристрій для його здійснення. Деклараційний патент на винахід 49253 А.- Украйна, 2002.- Бюл. № 9.

33. Gulyar SA, Limansky YP. Pain and color. Kiev-Donezk: Biosvet, 2004. 122 p. (in Russian). Гуляр С.А., Лиманский Ю.П., Тамарова З.А. Боль и ивет.- Киев-Донецк: БИОСВЕТ, 2004.- 122 c.

34. Gulyar SA, Kosakovsky AL. eds. BIOPTRON-PILER-light application in medicine. Kiev: BIP NAS of Ukraine and NMAPO of Ministry of Health of Ukraine, 2006. 152 p. (in Ukrainian). Гуляр С.О., Косаковський А.Л. (ред). Застосування БІОПТРОН- ПАЙЛЕР-світла в медицині.Київ: вид-во ІФБ НАН Украӥни та КМАПО МОЗ України, 2006.- 152 c.

35. Gulyar SA, Limansky YP. Permanent magnetic fields and their use in medicine. Kiev:BIP NAS of Ukraine, 
2006; 320 p. (in Russian). Гуляр С.А., Лиманский Ю.П. Постоянные магнитные поля и их применение в медицине. Киев: Ин-т физиологии им. А.А. Богомольца НАН Украины, 2006.- 320 c

36. Ho M-W, Knight DP. The acupuncture system and the liquid crystalline collagen fibers of the connective tissues. Am. J. Chin. Med. 1998; 26(3-4):251-263.

37. Iljin VN. Correlation between human geomagnetic activity and heart rate in the Antarctic area. In: Bul. Ukrain. antarkt. center, ed. PF Gozhik. Kiev: UAC MinSci Ukraine, 1987; 1:255-258 (in Russian). Ильин В.Н. и соавт. Корреляция между геомагнитной активностью и сердечным ритмом человека в районе Антарктики // Бюл. Укр. антаркт. центру, ред. П.Ф. Гожик.- Київ: УАЦ Міннауки Украӥни, 1987.- Вип.1.- С. 255-258.

38. Iljin VN, Gulyar SA. Influence of meteorological factors on human body during transatlantic crossings and stay at the Antarctic station "Academician Vernadsky", ibid. 1988; 2: 238-244 (in Russian). Ильин В.Н., Гуляр С.А. Влияние меторологических факторов на организм человека во время трансатлантических переходов и пребывания на антарктической станции «Академик Вернадский» // Там же.- 1988.- Вип.2.- С. 238-244.

39. Isakov VL.The main issues of guideline developments in laser medicine. In: The use of lasers in biology and medicine. Kiev,1995; p. 7-20 (in Russian). Исаков В.Л. Основные вопросы разработки методических рекомендаций по лазерной медицине.- В кн.: Применение лазеров 8 биологии и медицине.- Киев, 1995.- С. 7-20.

40. Isakov VL. Ultrasound and laser therapy of urogenital tract diseases. In: Internat. Scientific-practical conf. Medical rehabilitation, balneology and physiotherapy. Yalta. 1999; p. 282-283 (in Russian). Исаков В.Л. Ультразвуковая и лазерная терапия заболеваний урогенитального тракта // Междунар. науч-практ.конф. «Медиц. реабилитация, курортология и физиотерапия».- Ялта.- 1999.- С. 282-283.

41. Kalistchuk TM, Matyash MM. Internat. Scientific-practical conference Medical rehabilitation, balneology and physiotherapy. Yalta, 1999; p.159-160 (in Russian). Калішук Т.М., Матяш М.М. и соавт. // Междунар. научпракт. кон $б$. «Медиц. реабилитация, курортология и физиотерапия».- Ялта.- 1999.- С. 159-160.

42. Katchan AT. Anatomical and topographical location of corporal acupuncture points, and indications for their use. Voronezh: University Press. 1990; 144 p. (in Russian). Качан А.T. и соавт. Анатомо-топографическое расположение корпоральных точек акупунктуры и показания к их применению. Воронеж: Изд-во Воронеж. ун-та, 1990.-144 c.

43. Kirukhin IF, Sarachan TA, Pereskokova II. Biological and medical properties of the water treated by linearly polarized light. N: Anthology of light therapy, Proc. Kiev: BIP NAS of Ukraine, 2009; p. 480-483. (in Russian). Кирюхин И.Ф., Сарачан Т.А., Перескокова И.И. Биологические и лечебные свойства воды, обработанной линейнополяризованным светом // Антология светотерапии, ИФБ НАНУ, 2009,c. 480-483.

44. Kolbun ND. Theory and practice of information-wave therapy. Kiev: Biopolis, 1996. 268 p. (in Russian). Колбун Н.Д., Лиманский Ю.П. Атлас зон информационноволновой терапии.- Киев: Биополис, 2000.- 112 c.

45. Kolbun ND, Limansky YP. Atlas of information-wave therapy. Kiev: Biopolis, 2000. 112 p. (in Russian). Колбун Н.Д., Околитенко Н.И. ИВТ- целительная волна.Житомир: Волынъ.- 2001.- 64 с.

46. Kolbun ND, Okolytenko NI. IWT- healing wave. Zhitomir: Volyn, 2001. 64 p.( in Russian).
47. Korotkov KG. Development of scientific grounds and practical implementation of biotechnical computer measurement systems analysis of gas discharge glow induced by objects of biological nature [Dissertation]. S-Petersburg; 1999. 205 p. (in Russian). Коротков К.Г. Разработка научных основ и практическая реализация биотехнических измерительно-вычислительных систем анализа газоразрядного свечения, индуцированного объектами биологической природы: Дис. ... д-ра техн. наук. С-Петербург.- 1999.- 205 c.

48. Kulikovich YM, Tamarova ZA. Role of opiate receptors in analgesia evoked by the influence of millimeter range waves of low intensity on acupuncture points. Medicine prospects. 1999; 4(3), Part 1:9-14 (in Russian). Куликович Ю.М., Тамарова З.А. Роль опіатних рецепторів у аналгезї, викликаній дією на точку акупунктури низькоінтенсивних міліметрових хвиль // Медичні перспективи,- 1999.- 4, № 3, ч. 1.- C. 9-14

49. Langevin HM, Yandow JA. Relationship of acupuncture points and meridians to connective tissue planes. Anat. Rec. (New Anat.).2002; 269, (6):257-265.

50. Limansky YP. The hypothesis of acupuncture points as a multimodal system receptors ecoceceptive sensitivity. Fiziol. J. 1990; 36(4):115-121 (in Russian). Лиманский Ю.П. Гипотеза о точках акупунктуры как полимодальных рецепторах системы экоцептивной чувствительности // Физиол. журн., 1990.- 36, № 4.C. 115-121.

51. Limansky YP. Physiology of pain. Kiev: Health Protection, 1986. 96 p.( in Russian). Лиманский Ю.П. Физиология боли.- Киев: Здоров'я, 1986.- 96 с.

52. Limansky YP. Mechanisms of primary reception of electromagnetic waves in the optical range. Anthology of light therapy, Proc. Kiev: BIP NAS of Ukraine, 2009; p.93-104 (in Russian). Лиманский Ю.П. Механизмы первичной рецепции электромагнитных волн оптического диапазона // Антология светотерапии, ИФБ НАНУ, 2009, c. 93-104.

53. Limansky YP, Gulyar SA, Tamarova ZA. BIOPTRON-induced analgesia: 10. Involvement of opioid-ergic system in analgetic effect of polarized light on antinociceptive acupuncture point. Anthology of light therapy, Proc. Kiev: BIP NAS of Ukraine, 2009; p. 266-275 (in Russian). Лиманский Ю.П., Гуляр С.А., Тамарова З.А. Биоптронанальгезия: 10. Участие опиоид-эргической системы в анальгетическом эффекте через противоболевую точку акупунктуры // Антология светотерапии, ИФБ НАНУ, 2009, c. 266-275.

54. Limansky YP, Gulyar SA, Tamarova ZA. Mechanisms of action of electromagnetic waves in the visible range on living organisms. Anthology of light therapy, Proc. Kiev: BIP NAS of Ukraine, 2009; p. 105-111 (in Russian). Лиманский Ю.П., Гуляр С.А., Тамарова З.А. Механизмы действия электромагнитных волн видимого диапазона на живые организмы // Антология светотерапии, ИФБ HAHУ, 2009,c. 105-111.

55. Limansky YP, Gulyar SA, Tamarova ZA. BIOPTRON-analgesia: 1. Analgesia phenomenon of PILER-light BIOPTRON device action on acupuncture points // Anthology of light therapy, Proc. Kiev: BIP NAS of Ukraine, 2009; p. 184-189 (in Russian). Лиманский Ю.П., Гуляр С.А., Тамарова 3.А., Костюк О.И., Митрузаева В.А. БИОПТРОН-анальгезия: 1. Феномен анальгезии при действии ПАЙЛЕР-света аппарата БИОПТРОН на точку акупунктуры // Антология светотерапии, ИФБ HАHУ, 2009, c. 184-189.

56. Limonad Y, Ziganov AI. Live fields of arcitecture. Obninsk: Titul, 1997. 208 p. (in Russian). Лимонад М.Ю., 
Цыганов А. И. Живые поля архитектуры.- Обнинск: Титул, 1997.- 208 c.

57. Luvsan G. Traditional and modern aspects of modern reflexology. Moskow: Nauka, 1992, 3rd ed. 576 p. (in Russian). Лувсан Гаваа. Традиционные и современные аспекты современной рефлексотерапии - 3-е изд.,- М.: Наука, 1992.- 576 c.

58. Makatz V, Makatz D, Nagajtchuk V, Makatz D. Functional-energy system of biological objects (theory and error of Chinese Zhen-jeou therapy. Vinnitsa: Veles, 2002. 155 p. (in Russian). Макац В., Макац Д., Нагайчук В., Макац Д. Функционально-энергетическая система биологических объектов (теория и ошибки китайской чжень-цзю терапии. Винница: Велес, 2002.- 155 с.

59. Macheret EL, Samosyuk IZ. Guide on refleksotherapy. Kiev: Vyshcha school, 1989. 479 p. (in Russian). Мачерет Е.Л., Самосюк И.З. Руководство по рефлексотерапии.- К: Выщца школа, 1989.- 479 с.

60. Macheret EL, Korkushko AO. Basics of electro and aqupuncture. Kiev: Health, 1993. 389 p. (in Russian). Мачерет Е.Л., Коркушко А.О. Основы электро- и акупунктуры.- К.: Здоровъя, 1993.- 389 с.

61. Maiserov EE, Blinkov IL. Bioresonance therapy: Method. recomendations, Moskow: Sci-practical Center of traditional medicine and homeopathy. 2000. 27 p. (in Russian). Мейзеров Е.Е., Блинков И.Л., Готовский Ю.В., Королева М.В., Катораин В.С. Биорезонансная терапия: Метод. рекомендации.- М.: Науч.-практ. центр традиц. медицины и гомеопатии МЗ РФ.- 2000.- 27 c.

62. Muehsam DJ, Pilla AA. The sensitivity of cells and tissues to exogenous fields: effects of target system initial state. Bioelectrochem. Bioenerg. 1999; 48(1):35-42.

63. Musil Y, Novakova O, Kunz K. Modern biochemistry in schemes. Moskow: Mir 1984, 2nd ed. 216 p. (in Russian). мусил Я., Новакова О., Кунц К. Современная биохимия $в$ схемах. Пер с англ.- 2-е изд.- М.: Мир, 1984.- 216 с.

64. Navratil L, Dilevsky I, Kyplova Y. Polarized light phototherapy by device BIOPTRON. In: Intern. sci-pract. conf. Medicine, rehabilitation, balneology and physiotherapy, Yalta, 1999; p. 135-136 (in Russian). Навратил Л., Дьлевски И., Кьмлллова Я. Фототерапия поляризованным светом аппарата БИОПТРОН.- В кн.: Междунар. науч.практ.конф. «Медиц. реабилитация, курортология и физиотерапия». Ялта.- 1999.- С. 135-136.

65. Perechrestenko AP. Immunological evaluation of the effectiveness of polarized application on the body of patients with psoriasis. In: Intern. sci-pract. conf. Medicine, rehabilitation, balneology and physiotherapy, Yalta, 1999; P. 262 (in Russian). Перехрестенко А.П., Барабанчик Т.В., Патока В.В. Иммунологическая оценка эффективности поляризованного света на организм больных псориазом // Там же.- С. 262.

66. Pesikov YS, Rybalko SYa. Atlas of clinical auriculotherapy. Moskow: Medicine, 1990. 256 p. (in Russian). Песиков Я.С., Рыбалко С.Я. Атлас клинической аурикулотерапии.- М.: Медицина, 1990.- 256 с.

67. Poroshina OV. Treatment of neurodermatitis and allergic dermatitisin children with the use of EHF-therapy. In: Intern. Sci. pract. conf. Medicine, rehabilitation, balneology and physiotherapy, Yalta, 1999; p. 209-210 (in Russian). Порошина О.В. Лечение нейродермитов и аллергических дерматитов у детей с применением КВЧтерапии // Там же.- C. 209-210.

68. Presman AS. Electromagnetic fields and live nature. M.: Nauka. - 1968.- 288 p. (in Russian). Пресман А.С. Электромагнитные поля и живая природа.- М.: Наука.1968.- 288 c.
69. Presman A.S. Electromagnetic alarm in the living nature. Moskow: Soviet radio, 1974. 64 (in Russian). Пресман А.С. Электромагнитная сигнализация в живой природе.- М.: Советское радио.- 1974.- 64 c.

70. Pukavsky KV, Borodyuk OO. Application of weak electromagnetic fields of ultra low frequency for treatment and prophylaxis of vegetative crisises. In: Intern. Sci-pract. conf. Medicine, rehabilitation, balneology and physiotherapy. Yalta, 1999; p. 178-179 (in Russian). Пукавсъкий К.В., Бородюк О.О. Використанння слабких електромагнітних полів дуже низької частоти для лікування та профілактики вегетосудинних кризів.- В кн.: Междунар. науч-практ.конф. «Медиц. реабилитация, курортология и физиотерапия».-Ялта, 1999.- C. 178-179.

71. Ragulskaja MV, Kopejkin VV, Lubimov VV. Electromagnetic environmental safety of man. In: Space and Biosphere. Physical fields in biology, medicine and ecology: Intern. Sci-pract. conf. Medicine, rehabilitation, balneology and physiotherapy. Yalta: Partenit, 2001. p. 80-81(in Russian). Рагульская М.В., Копейкин В.В., Любимов В.В. Электромагнитная экологическая безопасность человека.- В кн.: Космос и биосфера. Физические поля в биологии, медицине и экологии: Тез. докл. Крым. междунар. семинара.- Крым: Партенит, 2001.- C. 80-81.

72. Samoilova KA, Obolenskaya KD, Vologdina AV. Single skin exposure to visible polarixed light induces rapid modification of entire circulating blood. 1. Improvement of rheologic and immune parameters. In: Proc. of Low-Power Light on Biological Systems IV. Stockholm, Sweden. Sept, 1998; p. 90-103.

73. Samosyuk IZ. System organization of functions and medical rehabilitation. In: Intern. sci and practical. conf. Medicine, rehabilitation, balneology and physiotherapy. Yalta, 1999; p. 30-31 (in Russian). Самосюк И.3. Системная организация функций и медицинская реабилитация.-В кн.: Междунар. науч.-практ. конф. «Медиц. реабилитация, курортология и физиотерапия».Ялma, 1999.- C. 30-31.

74. Samosyuk IZ. Therapy by Millimeter diapason waves (EHF-therapy, MRI, VPI). In: All Ukrainian assoc. of physiotherapists and health resort. Kiev, 1999, issue 1.2. 199 p. (in Russian). Самосюк И.З., Чухраев Н.В., Шимков Г.Е., Бицон А.В. Терапия электромагнитными волнами миллиметрового диапазона (КВЧ-терапия, МРТ, ИВТ) // Всеукр. ассоц. физиотерапевтов и курортологов, выn.1.2.- Киев: 1999.- 199 с.

75. Sant-Dierdy A. Bioenergy. - Moskow: Fizmatgiz,1960. 250 p. (in Russian). Сент-Дъерди А. Биоэнергетика.- М.: Физматаиз.- 1960.- 250 c.

76. Shachbasov VG. The nature of biological responses to laser irradiation and the method of determining the change in the energy properties of irradiated objects. In: The use of lasers in biology and medicine. Kiev,1995. p. 181-186 (in Russian). Шахбазов В.Г. Природа реакций биологических объектов на лазерное облучение и методика определения изменения энергетических свойств облучаемьх объектов - В кн.: Применение лазеров в биологии имедицие. -Киев, 1995.- C. 181-186.

77. Starchenko MG, Anufriev VP, Anufrieva EI, Putina OP The thought and the heart. Arktur, 1999; 17:19-24 (in Russian). Старченко М.Г., Ануфриев В.П., Ануфриева Е.И., Путина О.П. Мысль и сердце // Арктур.- 1999.№ 17.- C. 19-24.

78. Syt'ko SP, Skripnik YA, Yanenko AF. Apparatus support of quantum medicine modern technology. Kiev: Fada, 
1999. 199 p. (in Russian). Ситько С.П., Скрипник Ю.А., Яненко А.Ф. Аппаратурное обеспечение современных технологий квантовой медицины.- К.: ФАДА, 1999.- 199 c.

79. Vajsyn' U. Sketches of Eastern medicine. St. Petersburg: Borey Art, 1998. 193 р. (in Russian). Вэйсинь У. Очерки восточной медицины. Санкт-Петербург: Борей Арт, 1998.- $193 \mathrm{c}$.

80. Ulashchyk VS. Current status and future directions of phototherapy. In: BIOPTRON devices - action and therapeutic application. Minsk, Biznesofset. 2001; p. 8-21 (in Russian). Улащик В.С. Современное состояние и перспективные направления фототерапии - В кн.: Аппараты БИОПТРОН - действие илечебное применение.Минск: Бизнесофсет.- 2001.- С. 8-21

81. Curl RF, Kroto H, Smalley RE. The Nobel Prize in Chemistry 1996. Nobelprize. org. Nobel Media AB 2014. Web. Accessed 31 Aug 2017. http://www.nobelprize.org/ nobel_prizes/chemistry/laureates/1996/.

82. Koruga D, Hameroff S, Loutfy R, Withers J, Sundereshan M. Fullerene C60: History, Physics, Nanobiology, Nanotechnology. 1993; Amsterdam: Elsevier (NorthHolland). 381 p.
83. Koruga D. Nanophotonic filter based on C60 for hyperpolarized light. Int. and European Pat. App. PCT/ EP2016/063174. 2016. Applicant: Fieldpoint, ZEPTER GROUP filed June 0920162015 and issued October 28,2016

84. Koruga, D. 2017. Hyperpolarized Light : Fundamentals of nano medical photonics. Belgrade: Zepter book world. 306 p. ( In Serbian).

85. Gulyar SA, Tamarova ZA. Modification of Polychromatic Linear Polarized Light by Nanophotonic Fullerene and Graphene Filter Creates a New Therapeutic Opportunities. J. of US-China Medical Science. 2017; 14(5), Sept.-Oct. (Serial Number 109): 173-191.

86. Gulyar SA, Tamarova ZA. Anti-pain and sedative action of polychromatic polarized light which passed through nanomodification by carbon nanofilters. In: Proc. XLVII Int. Sci-Pract. conf. Oct, 12-14, 2017. Kiev, 2017; p. 9597 (in Russian). Гуляр СА, Тамарова ЗА. Противоболевое и седативное действие полихроматического поляризованного света, получивщего наномодификацию углеродным нанофильтром. Матер. XLVII Междунар. науч-практ. конф. 12-14 окт. 2017, Киев, 2017, с.95-97. 